\title{
MASHARIF AL-ZAKAT: THE HADITH MAUDHU'I APPROACH
}

\author{
Ivan Rahmat Santoso ${ }^{1}$ \\ La Ode Ismail Ahmad ${ }^{2}$ \\ Muhammad Hasan ${ }^{3}$ \\ Indrawan $\mathrm{Aziz}^{4}$ \\ Muhammad Harsya Bachtiar ${ }^{5}$ \\ Universitas Negeri Gorontalo ${ }^{1}$ \\ Fakultas Tarbiyah dan Keguruan UIN Alauddin Makassar ${ }^{2}$ \\ Universitas Negeri Makassar ${ }^{3}$ \\ STIE NOBEL Indonesia Makassar ${ }^{4}$ \\ STIBA Makassar ${ }^{5}$ \\ ivan_santoso@ung.ac.id ${ }^{1}$
}

\begin{abstract}
The distribution of zakat (masharif al-zaka) is an important factor as an indicator of the optimal function of zakat. In addition to the qur'an, the zakat distribution mechanism should be based on valid traditions as references in its management. This study aims to analyze the distribution of zakat in the review of maudhu'iy hadith. The method used is a thematic approach (alhadith al-maudhu'i). The result of the research shows that the hadith that is being discussed is categorized as hasan lighairihi hadith, where the origin is dha'if but has reinforcement from other lines so that it is elevated to hasan lighairihi. In addition, the contents of the prophet's hadiths regarding mashârif al-zakât which are discussed do not contradict the verses of the qur'an, because they have the same meaning regarding the eight asnaf who are entitled to receive zakat.
\end{abstract}

Keywords: Masharif; Zakat; Distribution; Hadith; Maudhu'i method

\section{INTRODUCTION}

Shodaqoh is spending for other people. In the teachings of Islamic law, Shodaqah is an obligation for everyone who has excess assets from reasonable expenses for himself and his family. Because this Shodaqah is mandatory, the giving of shodaqah by the capable group can be enforced by the stakeholders who are given the authority. ${ }^{1}$ This minimal shodaqah whose collection can be enforced is what we know as zakat. Zakat is one of the main pillars of Islamic teachings. The urgency of zakat, which is the recommendation of Islam to pay zakat and give it to those who have the right on the condition that it reaches its nishab (minimum level of certain assets) has a very significant value in human life. A human being who is full of all the problems in his nature demands to always interact with others, both in material and non-material terms. $^{2}$

1 Arif Wibowo, "Distribusi Zakat Dalam Bentuk Penyertaan Modal Bergulir Sebagai Accelerator Kesetaraan Kesejahteraan," Jurnal IImu Manajemen UNY 12, no. 2 (2015): 28-43, https://doi.org/10.21831/jim.v12i2.11747.

${ }^{2}$ Mustaqim Makki, "Tafsir Ayat-Ayat Zakat Sebagai Penguat Konsep Filantropi Ekonomi Keummatan (Tafsir Verses Of Zakat As The Booster Of Public Economic Philanthropy Concept)," Qawãnï: Journal of Economic Syaria Law 3, no. 2 (2019): 117-37. 
One of the important studies in zakat is its distribution. Whether or not zakat can empower the community's economy really depends on how the distribution system is applied. ${ }^{3}$ The distribution of zakat can be categorized into two categories; consumptively and productively. Consumptive means that zakat assets are distributed directly to mustahiq (the group entitled to receive zakat) for consumptive use. While zakat assets are distributed productively means that mustahiq do not receive zakat assets which are directly used for consumption but must be cultivated first, either by the mustahiq himself or by the amil institution (zakat distributor), what is consumed is the result of this effort. ${ }^{4}$

The explanation regarding the distribution of zakat is clearly stated in the qur'an and Hadith, that those who are entitled to receive zakat are eight (8) groups (ashnaf). On the other hand, the existence of hadith as a second authoritative source after the qur'an occupies a central position in Islamic studies. Hadith authority originating from the Prophet Muhammad SAW received divine recognition and legitimacy. To get a complete understanding, it is very important if the hadiths regarding the distribution of zakat are studied with the maudhu'i approach. Several previous studies have discussed zakat with the same approach or on different topics, including the study of the hadith maudhu'i about zakat maal. ${ }^{5}{ }^{6}$, zakat fitrah ${ }^{7}$ as well as the role of the hadith of zakat in the modern era. ${ }^{8}$

This study is focused on the distribution of zakat in terms of the study of hadith maudhu'i. Based on the description in the background of the problem above, several sub-problems can be made as follows: a) How are the reviews of the Prophet's hadiths and traditions regarding mashârif al-zakât? b) What is the content of the Prophet's hadith regarding mashârif al-zakât? c) What is the urgency of mashârif al-zakât in the review of the Prophet's hadith?

\section{THEORETICAL REVIEW}

In the discussion of theoretical concepts the writer divides the terms of the discussion topic into two (2) terms, namely masharif and zakat.

3 Muchamat Amarudin, "Optimalisasi Dana Zakat di Indonesia (Model Distribusi Zakat Berbasis Pemberdayaan Ekonomi): Muchamat Amarudin," EKSYAR: Jurnal Ekonomi Syari'ah \&amp; Bisnis Islam 6, no. 01 SE- (August 26, 2019): 1-13, https://ejournal.staimtulungagung.ac.id/index.php/eksyar/article/view/380.

${ }^{4}$ Mubasirun Mubasirun, Distribusi Zakat dan Pemberdayaan Ekonomi Umat, INFERENSI, vol. 7, 2013, https://doi.org/10.18326/infs13.v7i2.493-512. INFERENSI. Vol. 7, 2013

${ }^{5}$ Muhammad Ali, "Zakat Mal Dalam Kajian Hadis Maudhu'i," Aqidah-Ta 1, no. Vol 1, No 1 (2015) (2015): 69-98, http://journal.uin-alauddin.ac.id/index.php/aqidah-ta/article/view/1310.

${ }^{6}$ Hamzah Hamzah, "Zakat Mal Dalam Perspektif Hadis Maudhu'iy," TASAMUH: Jurnal Studi Islam 11, no. 1 SE-Articles (April 1, 2019), https://doi.org/10.47945/tasamuh.v11i1.177.

7 Syarifuddin Syarifuddin, "Zakat Fitrah (Kajian Hadis Tematik)," Al-Hikmah Journal for Religious Studies 14, no. 1 (2013): 93-111.

${ }^{8}$ M Nurudin, "Transformasi Hadis-Hadis Zakat Dalam Mewujudkan Ketangguhan Ekonomi Pada Era Modern," ZISWAF, no. Vol 1, No 2 (2014): ZISWAF : Jurnal Zakat dan Wakaf (2014): 1-22, http://journal.stainkudus.ac.id/index.php/Ziswaf/article/view/1489. 


\section{A. Masharif}

Wherever these zakat assets are distributed, in Islamic sharia it is called masharif (مصارف). This word is the jama 'form of mashraf (مصارف), which means the allocation of assets. It is said sharafalmal means spending wealth. In the Qur'an, this word mashraf is also used:

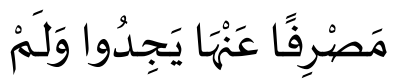

The Translation:

" and they find no place to turn to him. (QS. Al-Kahfi: 53) ${ }^{9}$

Meanwhile, the term mashraf or masharif means the people or parties who are entitled to receive the allocation of zakat assets. In simple language, people who are entitled to zakat property. In Indonesia, generally the term masharif zakat is better known as mustahiq, which means people who are entitled and of course what is meant is the property of zakat.

\section{B. Zakat}

Zakat is often termed the word حقّ ,صدقة or oفقة, but what is meant is shadaqah wajibah, haqq wajib and nafaqah wajibah specifically given to ashnâf eight. Zakat in terms of language (lughatan) has several meanings, namely blessing (albarakatu), growth and development (al-nama), holiness (al-taharatu) and success (alsalahu). Meanwhile, the meaning of zakat in the term (shar'iyah) is that zakat is part of the property with certain conditions, which Allah SWT requires the owner to give to the owner to be handed over to those who are entitled to receive it, with certain conditions as well. ${ }^{10}$

\section{RESEARCH METODOLOGY}

This research uses the maudhu'i approach method. The data collection used the takhrij method based on the hadith theme. The hadith criticism method is used in research with textual, intertextual, and contextual interpretation techniques to understand the contents of the hadith as a whole and comprehensively. To focus on the discussion in the research, the writer took one of the hadiths related to masharif zakat which was the object of study which was then analyzed using the maudhu'i method approach.

\section{RESEARCH RESULTS AND DISCUSSION}

\section{A. Takhrij Hadith, Descriptions of Sanad and Matan Hadiths Studied}

The hadith takhrij is carried out based on the method according to the book Mu'jam mufahras li al fadzil al hadis ${ }^{11}$ by J.A. Wenscik ${ }^{12}$ based on (1) the first lafadz

\footnotetext{
9 Yayasan Penyelenggara Penterjemah and Pentafsir Al-Qur'an, “Al-Qur'an Dan Terjemahnya," Jakarta: Departemen Agama, 1986. Lihat QS. al-Kahfi (18): 53.

${ }^{10}$ Ivan Rahmat Santoso, Manajemen Pengelolaan Zakat, Cet. I (Gorontalo: Ideas Publishing, 2016).

${ }^{11}$ Fu'ad 'Abd. al-Baqy Muhammad, Al-Mu;Jam Al-Mufahras Li Alfazh Al Hadists Al-Nabawy, juz II (Leiden, The Netherlands: E.J Brill, 1963).
} 
of the hadith, (2) all the lafadz in the hadith's matan, (3) the first rawi, (4) the quality of the hadith, (5) choosing one of the lafadz in the hadith. The hadith that will be examined is the riwaya of Sunan Abu Dawud, the pronunciation and translation of the hadith as follows:

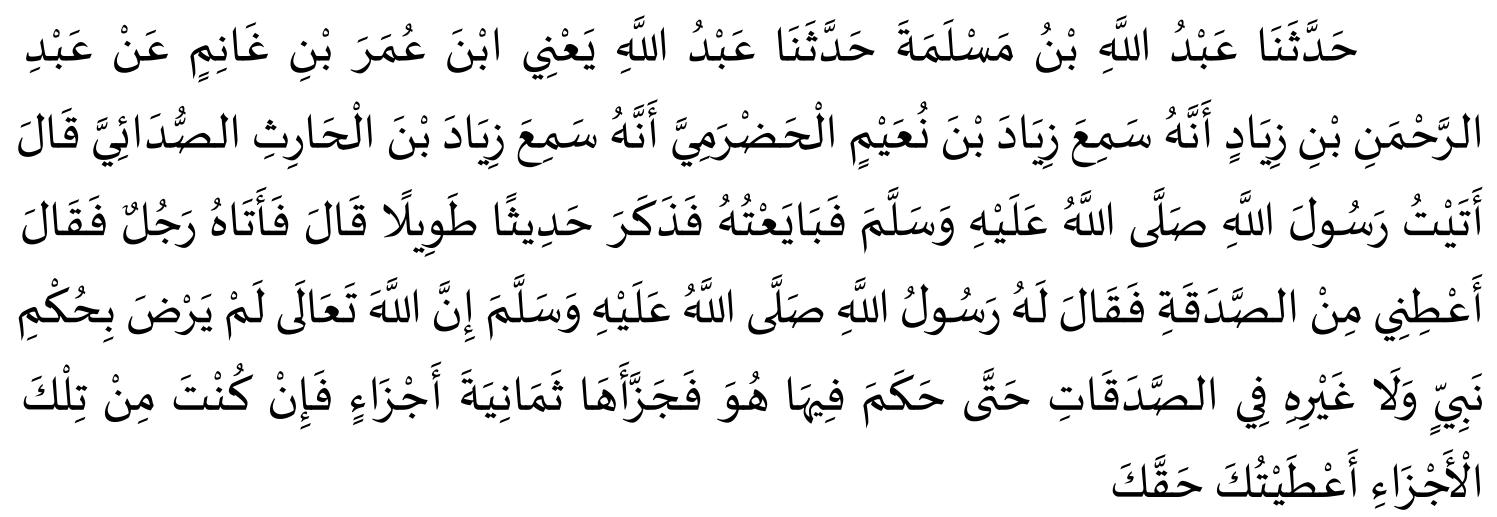

Meaning:

"Has told Us Abdullah bin Maslamah, has told Us Abdullah namely Ibn Umar bin Ghanim from Abdurrahman bin Ziyad that he heard Ziyad bin Nu'aim Al Hadhrami that he had heard Ziyad bin Harith Ash Shuda'I say; I went to the Prophet sallallaahu 'alaihi wasallam and took him. Then he mentioned a long hadith. He said; then there was someone who came to him and said; give me a portion of the alms! So the Messenger of Allah peace and prayer of Allah be upon him- said to him: "Surely Allah is not pleased with the law of a Prophet or another, He has determined it and has determined it for eight parts in the case of zakat, until He Himself decides. So Allah divides it into eight parts, if you are included in that part then I will give your rights to you."

\section{B. I'tibar Hadith}

Based on the search for the hadith which was the object of study in al-kutub altis'ah, only one history was found, namely the riwaya in Sunan Abu Daud. In this history, only one friend was found, namely Ziyad bin Al Harits radhiyallahu anhu. At the tabi'in level, only one riwaya was found, namely Ziyad bin Rabi'ah bin Nu'aim. Meanwhile, there are 3 (three) riwayas from among the Tabi'ut Tabi'in riwayas, namely Abdur Rahman bin Ziyad bin An'um, Abdullah bin 'Umar bin Ghanim and Abdullah bin Maslamah bin Qa'nab. Based on this information, in terms of quantity this hadith has the status of a week. The narrative sighah used are: haddasana, samia ', and qaala.

12 Constant Hames, "Wensinck (A.J.) Concordance et Indices de La Tradition Musulmane," Archives de Sciences Sociales Des Religions, 1993, 342, https://www.persee.fr/doc/assr_03355985_1993_num_82_1_1655_t1_0342_0000_2. 
Sanad Chart

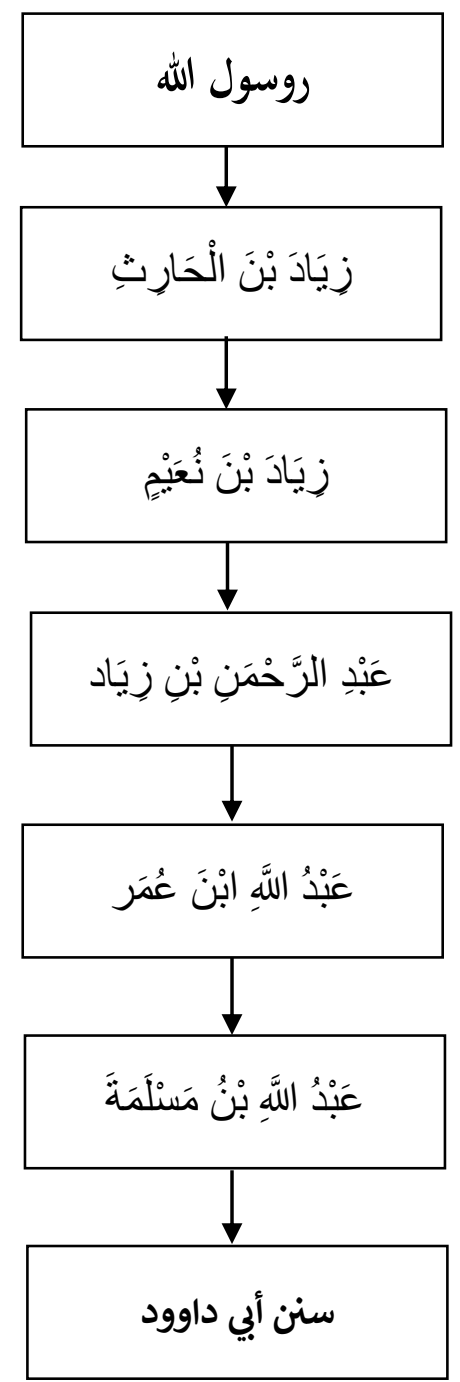

\section{Sanad's Criticism}

1. Imam Abu Dawud

The full name of Imam Abu Dawud is Abu Dawud Sulaiman bin al Asy'as bin Ishāq al-Azdy al-Sijistāniy. He was born in $202 \mathrm{H}$ in Sijistani, A city in Basra. He was born to coincide with the Abasiyah dynasty which was held by the khalifa al-Ma'mun. Azdiy is a large tribe in Yemen which will be the buddy of immigration to the city of Yasrib (Medina) and is the core of the al-Ansar (recipient) group in Medina. While the word al-Sijistani gives a sign that he comes from the area, which is a well-known area in southern India, but there are those who argue (Ibn al-Subki and Ibn Hallikan) that he is the name of an area in Yemen and some argue that Sijistani is an area that is located between Iran and Afghanistan (Kabul). As a prolific scholar of Mutaqaddimin, he always used his time to study and worship. Unfortunately, however, there is very little information about Abū Dāwud's childhood life. While in his adult life, many narrations say that he was one of the well-known scholars of hadìts.

Lots of praise and adulation from prominent figures among imams and scholars of hadith and other disciplines that flowed to Imam Abu Daud Rahimahullah, 
including; Abdurrahman bin Abi Hatim said: Abu Daud Tsiqah, Imam Abu Bakr Al Khallal said: Imam Abu Daud was an imam who was put forward in his day, Ibn Hibban said: Abu Daud was one of the world's priests in the field of science and fiqh and Musa bin Harun said: Abu Daud was created in the world for hadith and in the hereafter for Heaven, and I do not see anyone as superior to him.

2. Abdullah bin Maslamah

Full name: Abdullah bin Maslamah bin Qa'nab ${ }^{13}$

Circles: Tabi'ut Tabi'in among the common people

Kuniyah: Abu 'AbdurRahman

The land of his life: Madinah

Died: $221 \mathrm{H}$

Jarah / Ta'dil

Ibnu Hibban: mentioned in 'atstsiqaat

Ibnu Hajar: $t$ siqah worship expert

Abu Hatim: tsiqah hujjah

3. Ibnu Umar bin Ghanim

Full name: Abdullah bin 'Umar bin Ghanim ${ }^{14}$

Circles: Tabi'ut Tabi'in among the common people

Kuniyah: Abu 'Abdur Rahman

The land of his life: Ifriqiyah

Died: $190 \mathrm{H}$

Jarah / Ta'dil

Abu Hatim: Majhul

Ibnu Yunus: Tsiqah

Abu Daud: the hadith is straight

Ibnu Hibban: Tsiqah

Adz Dzahabi: the hadith is straight

4. Abdurrahman bin Ziyad

Full name: Abdur Rahman bin Ziyad bin An'um ${ }^{15}$

Circles: Tabi'ut Tabi'in among the elderly

Kuniyah: Abu Ayyub

The land of his life: Maru

Died: $156 \mathrm{H}$

Jarah / Ta'dil

Ahmad bin Hambal: laisa bi syai'

Yahya bin Ma'in: dla'if

Ya'kub bin Sufyan: la basabih

Abu Zur'ah: dla'if

13 Sa'id al-Mulk Abu Nasr 'Ali bin Hibbatillah bin Ma'ku, Al-Mausu'ah Al-Mujizah Fi AlTarikh Al-Islami, juz V, Cet (Beirut: Dar al-Kutub al'Ilmiah, 1990).

${ }^{14}$ Abu al-Fadl Ahmad bin 'Ali bin Muhammad bin Ahmad bin Hajar al-Asqalani, Tahzib AlTahzib, juz I, Cet (Beirut: Dar al-Fikr al-'Arabiy, 1984).

15 Abdurrahman bin Ahmad bin Yunus al-Sadafi Abu Sa'id, Tarikh Ibn Yunus Al-Misr, juz I, Cet (Beirut: Dar al-Kutub al-'Ilmiah, 1421). 
AnNasa'i: dla'if

IbnuKharasy: matruk

As Saji: dla'if

Ibnu Hajar al 'Asqalani: dla'if

Adz Dzahabi: dla'if

5. Ziyad bin Nu'aim Al Hadhrami

Full name: Ziyad bin Rabi'ah bin Nu'aim ${ }^{16}$

Circles: Middle class tabi'in

Kuniyah: -

The land of his life: Maru

Died: $95 \mathrm{H}$

Jarah / Ta'dil

Ibnu Hibban: mentioned in 'atstsiqaat

Ya'qub bin sufyan: Tsiqah

Adz Dzahabi: Tsiqah

IbnuHajar al 'Asqalani: Tsiqah

6. Ziyad bin Harits Ash Shuda'I

Full name: Ziyad bin Al Harits ${ }^{17}$

Circles: Shahabat

Kuniyah: -

The land of his life: -

Died: -

Jarah / Ta'dil

Ibnu Hajar al 'Asqalani: Shahabat

Based on the sanad criticism that has been made, it can be concluded that the hadith sanad is weak / Dha'if because one of the rawi (Abdur Rahman bin Ziyad bin An'um) has problems (rawi who are weak in their rawi (weak / rote defect, weak in knowledge, weak in religion) in the hadith so that it does not qualify as a sahih or hasan hadith.

\section{Increasing Pronunciation-pronunciation Research}

Research on the hadith observations which were the object of study, it was found that the hadith in al-kutub al-tis'ah was found in several source books with the following pronunciation variants:

1. Sunan Daruquthni with 1 riwayah:

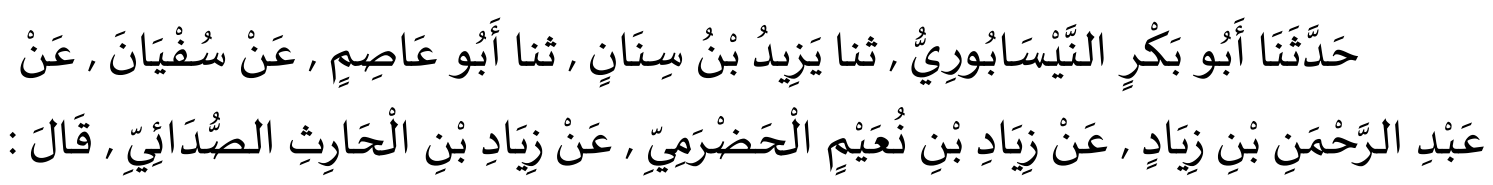

${ }^{16}$ Abu 'Abillah Muhammad bin Sa'id bin Mani' al-Hasyimi, Tabaqah Al-Qubra (Madinah alMunawwarh: Maktabah al-'Ulum wa al-Hukmi, 1408).

17 Muslim bin al-Hajjaj Abu al-Hasan al-Qusyariyyi al-Naisaburi, Kuniyah Al-Asma, juz. II (Madinah al-Munawwarh: Maktabah al-'Arabiyyah, 1984). 


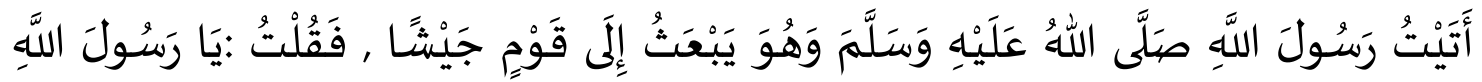

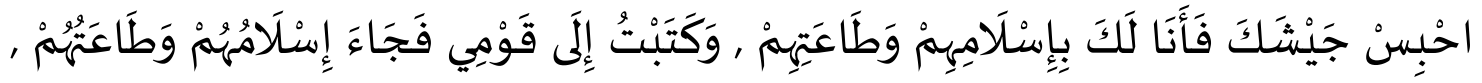

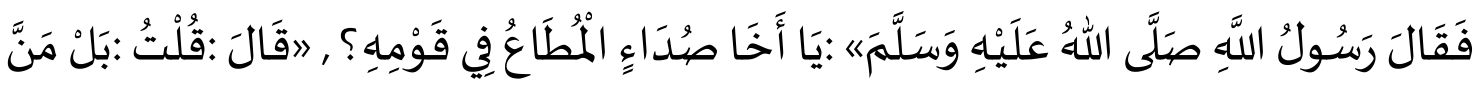

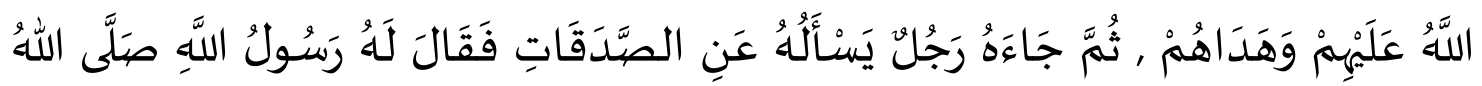

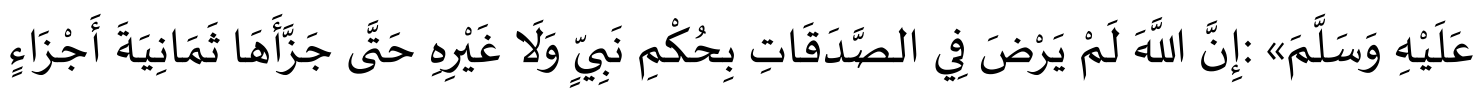

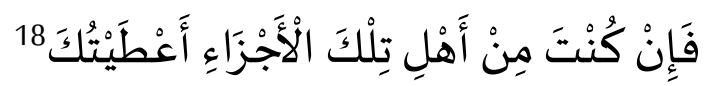

Meaning:

"Abu Bakr An-Naisaburi told us, Yazid bin Sinan told us, Abu Ashim told us, from Sufyan, from Abdurrahman bin Ziyad, from Ziyad bin Nu'aim Al Hadhrami, from Ziyad bin Al Harits Ash-Shuda'i, he said: I came to see Rasulullah $S A W$ and he was sending troops to a people. Then I said, "O Messenger of Allah, hold back your troops, I am the guarantee of their Islam and their obedience. And I write for my people, then comes their Islam and their obedience. So Rasulullah SAW said," O brother of Shuda who is obeyed among his people. " said, I said, "Even Allah has given them grace and showed them." Then someone came to him asking for shodaqoh, the Rasulullah SAW said to him, "Verily Allah does not accept this shodaqoh by the law of His Prophet and also others, until dividing it into eight parts. If you are among those who are entitled to that part, then I will definitely give it to you."

2. Sunan Abu Daud with 2 riwayah:

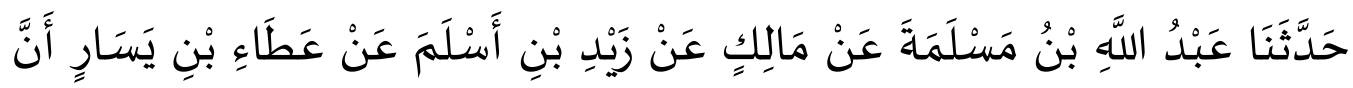

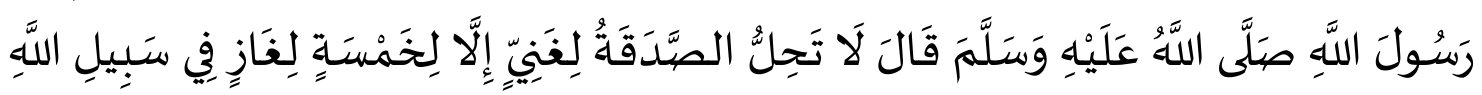

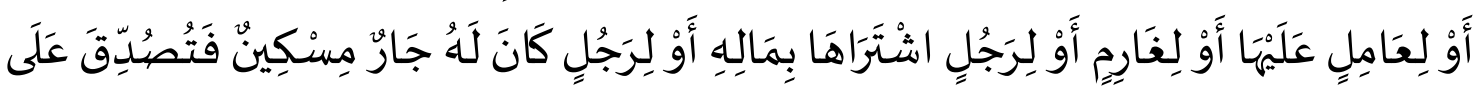

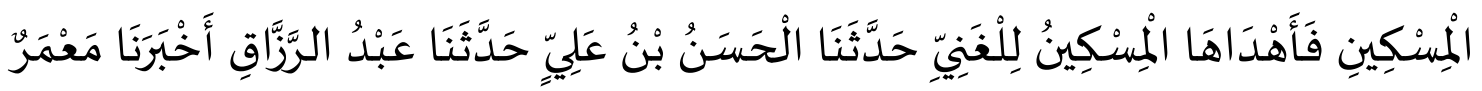

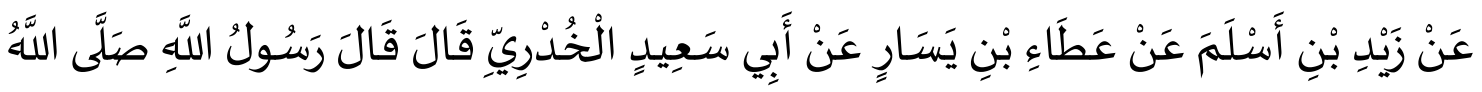

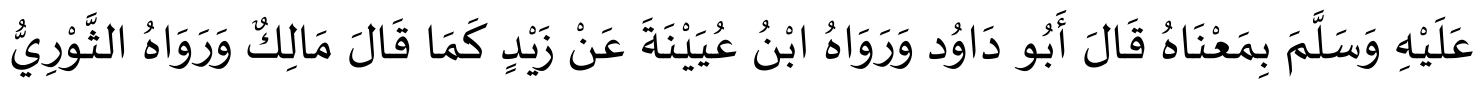

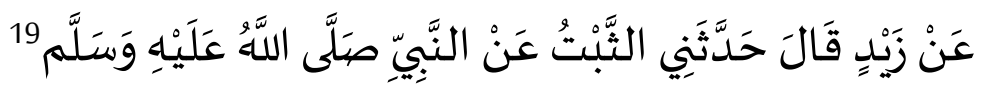

Meaning:

"Has told Us Abdullah bin Maslamah from Malik from Zaid bin Aslam from 'Atha bin Yasar that the Messenger of Allah -peace and prayer of Allah be upon him-said: "Zakat is not lawful for the rich except for five people, namely those

${ }^{18}$ Ibnu Mubarak Abi Sa'adah Mubarrak, An-Nihayah Fi Gharib Al-Hadits Wal Atsar (Dar AlKutub, 1979), Hadits Number: 1630.

${ }_{19}$ Abu Daud Sulaiman bin Asy'ats as-Sijistani, Matan Sunan Abu Daud, Jilid 1 (Baitul Afkar ad-Dauliyyah, n.d.), Hadits Number: 1393. 
who fight in the way of Allah, or officers. zakat, or someone who owes money, or someone who buys it with his property, or a person whose neighbor is poor then the poor person is given zakat, then he gives it to a rich person. "Having told Us Al Hasan bin Ali, has told Us Abdurrazzaq, has reported to Us Ma'mar from Zaid bin Aslam from 'Atha' bin Yasar from Abu Sa'id Al Khudri, he said: Rasulullah sallallahu 'alaihi wa sallam said: "....." is the same as the meaning of the hadith. Abu Daud said: Ibn 'Uyainah has narrated it from Zaid it has been said by Malik. And Ats Tsauri has narrated it from Zaid, he said: has told me Ats Tsabtu from the Prophet sallallaahu 'alaihi wa sallam."

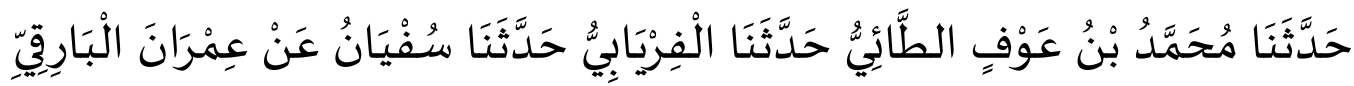

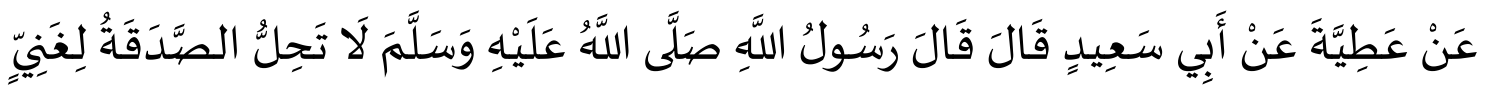

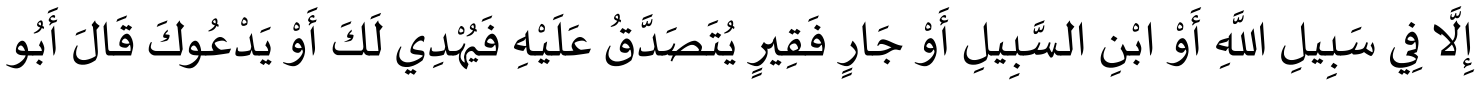

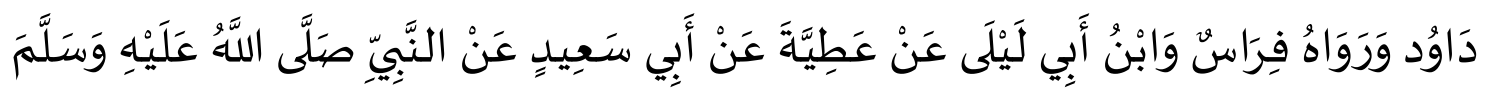

The meaning:

"Having told Us Muhammad bin 'Auf Ath Thai, had told Us Al Firyabi, had told Us Sufyan from Imran Al Bariqi from' Athiyyah from Abu Sa'id, he said: Rasulullah sallallahu 'alaihi wa sallam said: "It is not halal. zakat for rich people, except in the way of Allah, or people who are traveling, or neighbors who are poor who are given zakat and then give gifts to you or invite you. " Abu Daud said: and the hadith was narrated by Firas, and Ibn Abu Laila from 'Athiyyah, from Abu Sa'id from the Prophet sallallaahu' alaihi wa sallam like that."

3. Sunan Ibnu Majah with 1 riwayah:

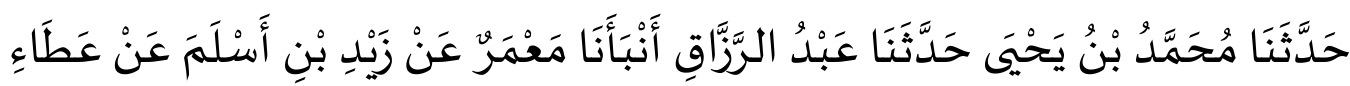

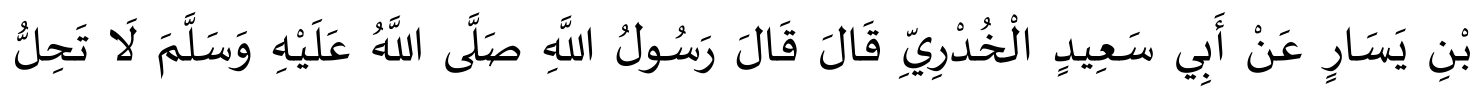

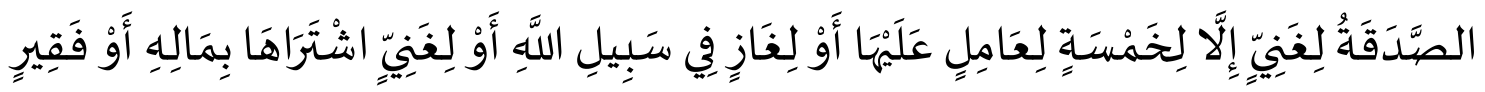

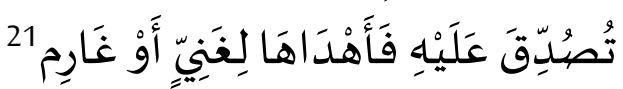

The meaning:

"Having told us Muhammad bin Yahya said: had told us Abdurrazaq said: has told us Ma'mar from Zaid bin Aslam from 'Atha bin Yasar from Abu Sa'id Al Khudri he said: "Rasulullah sallallahu' alaihi wa sallam said: "Shodaqoh giving is not lawful to be owned by someone who is well off except for five people: his

${ }^{20}$ Abu Daud Sulaiman bin Asy'ats as-Sijistani, Matan Sunan Abu Daud, (Riyadh: Baitul Afkar ad-Dauliyyah), Hadits Number: 1637.

${ }^{21}$ Abdullah Muhammad bin Yazid bin Majah ar-Rabi'i Al-Qazwini, Sunan Ibnu Majah, Cet. II, (Riyadh: Daar ul Ma'arif Linnasyri Wattaauzi', n.d.), Hadits Number: 1831. 
amil, a person who jihad in the way of Allah, a rich person but he gets it by other means (buying / gifts, such as dowry etc.), poor people who get shodaqoh are then given. to the rich, and to the people in debt."

4. Imam Malik dengan 1 riwayat:

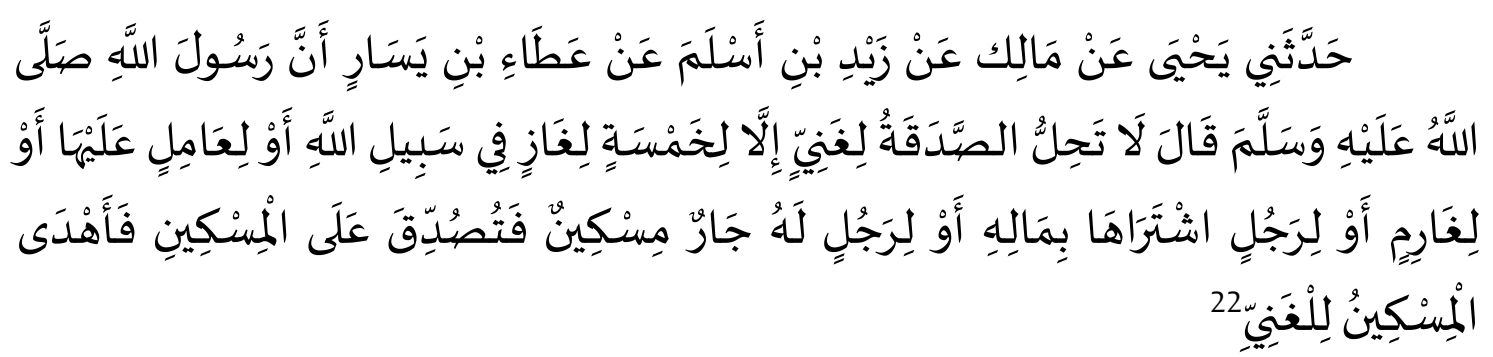

The meaning:

"Has told me Yahya from Malik from Zaid bin Aslam from 'Atha bin Yasar Rasulullah sallallahu' alaihi wa sallam said: "Zakat is not permissible for the rich except for five groups: people who fight in the way of Allah, collectors of zakat, people who are in debt, people who buy zakat assets with their assets, people who have poor neighbors who are given zakat assets, then the poor person gives gifts to the rich person."

After comparing the pronunciation variants of the 5 riwayah above, it can be concluded that these traditions indicate that bi al-ma'na riwayah occurred. Even so, on the whole these traditions do not contradict each other because they are substantially the same in content.

\section{E. Research on Hadith Content}

The content of the hadith above is related to the distribution of zakat. The explanation of the hadith shows that the distribution of zakat must be based on sharia. The Shari'a has emphasized that the distribution of zakat is only intended for depalan asnaf (mustahiqin) as stated in the word of Allah, so that it does not contradict the verses of the qur'an. As the word of Allah Almighty QS. At-taubah [9]: 6023

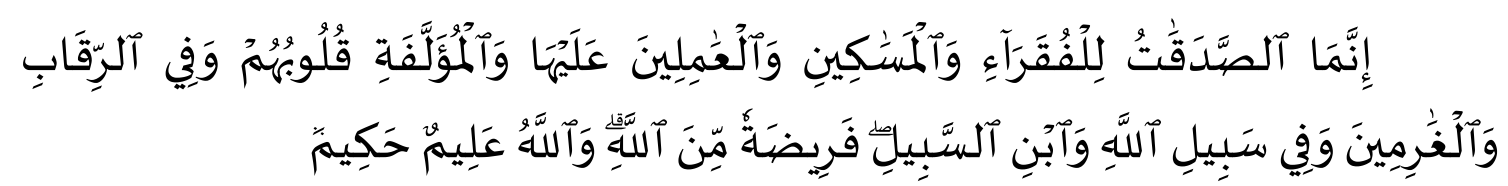

Translation:

"In fact, zakat-zakat is only for the needy, the poor, the administrators of zakat, the converts who are persuaded by their hearts, for (freeing) slaves, people in debt, for the way of Allah and for those who are is on the way, as a decree which Allah obliges, and Allah is All-Knowing, Most Wise."

${ }^{22}$ Abu Abdullah Malik bin Anas bin Malik bin Abu Amir Al-Ashbahi, Muwatha’ Malik (Darul Ma'rifah, n.d.), Shahih (29-657)

23 Yayasan Penyelenggara Penterjemah and Pentafsir Al-Qur'an, “Al-Qur'an Dan Terjemahnya," Jakarta: Departemen Agama, 1986, Lihat QS. al-Taubah (9): 60. 


\section{F. Natijah al-Hadith}

Based on the criticism of the hadith above, both in terms of sanad and matan, it is concluded that the hadith which is the object of study is considered hasan lighairihi hadith, where it comes from dha'if but has reinforcement from other lines so that it is elevated to hasan lighairihi. In this hadith sanad there is a dha'if because one of the rawi is in the category of dhoif, but this hadith is strengthened from other hadith lines and does not contradict the verses of the qur'an so that it does not contain syadz and 'illah.

\section{G. Fiqh Hadith Masharif Zakat}

The distribution of zakat (mashârif al-zakât) is the distribution of zakat to those who are entitled to receive it (al-mustahaqûn laha). ${ }^{24}$ To distribute zakat properly, it requires a separate understanding (fiqh) which is based on the arguments contained in the shari'a texts which are explored through the linguistic approach (alqowâid al-lughawiyyah) and the approach of sharia objectives (maqâshid asysyarîah). ${ }^{25}$ In our opinion, the two approaches constitute an inseparable unity, so that the texts of the shari'a may not contradict the will of asy-Syâri', as is the purpose of sharia (maqâshid asy-syarî'ah) which cannot contradict the texts of the sharia law

The linguistic principles approach is used to explore laws that come from the syara'text (al-Qur'an and / or al-Sunnah). The linguistic approach is used in addition to aiming to determine / issue the law of zakat (istinbâth al-ahkâm) from the source (mashâdir al-ahkâm al-syar'iyah), also to find out the maqâshid asy-syarîah from the texts themselves. The purpose of sharia is impossible to know except through the linguistic approach itself to reveal the true wisdom / meaning that exists in the texts of the shari'a. These two approaches are often used by scholars to perform legal istinbath, both related to the construction of fiqh and fatwa. The law of zakat distribution can be extracted from texts related to the distribution of zakat, both linguistically and maqâshid syarîah. Before tracing the verse, the Prophet himself was willing to give zakat even though someone asked for it.

Ibnu Katsir explains in his interpretation that when Allah mentions the rejection of the ignorant hypocrites and their condemnation of the Messenger of Allah in the matter of distributing shodaqoh. Allah explained to determine the division and explained the law and the one who handled this matter was Allah Himself. He does not represent the distribution to anyone, then $\mathrm{He}$ is the one who divides the shadaqah to those groups. ${ }^{26}$ This means that when Allah himself divides the shadaqah, then the distribution of shadaqah carried out by humans must be in accordance with His will. If amil (either alone or through amil zakat body / institution) is able to carry out Allah's mandate in distributing zakat, then His pleasure will approach him. Likewise, on the other hand, when amil betrays Allah's mandate, of course what comes to him is His wrath.

This word innamâ indicates that zakat is only given to the eight groups and not to the others. ${ }^{27}$ According to Al-Qahthani to tasharuf zakat to other than those that

\footnotetext{
${ }^{24}$ Wahaf Al-Qahthâni, Masharif Al-Zakat Fî Al-Islâmî (Riyâd: Muasasah al-Jarîsî, 1431).

${ }^{25}$ alKhadimi, Ilm Al- Maqâshid Al-Syar'iyyah (Riyadh: Maktabah Abikan, 1421).

${ }^{26}$ Ibn Katsir, Tafsir Al-Qur'ân Al- 'Adhîm, IV (Riyâd: Dâr al-Thyibah, 1418).

${ }^{27}$ Kuwait. Wizārat al-Awqāf wa-al-Shu'ūn al-Islāmīyah, Al-Mawsu'ah Al-Fiqhiyyah (Wizarat al-Awqaf wa al-Shu'un al-Islamiyah, 1982), https://books.google.co.id/books?id=VZdTnQAACAAJ.
} 
have been determined. Tasharuf zakat to build mosques, repair roads, buy shrouds, etc. is a bad deed because Allah has allocated eight asnaf through lafadz innamâ. The purpose of the lafadz is to limit the provisions that have been mentioned and deny others. Imam Ibn Qadâmah stated: "We do not know the difference of opinion among the scholars who prohibit the distribution of zakat to other than ansaf, except the opinion of Anas and Hasan. The point is that the scientists agree to prohibit the distribution of zakat to other than eight asnaf, except for only a few who allow it

The special distribution to the eight asnaf is a form of command that must be carried out. The form of the command can be seen from lafadz farîdhatan mina Allâh which means provision from Allah. Because this division has become a stipulation from Allah, then existence must be followed. Besides that, the division into eight asnaf is a form of notification of Allah to His servants (mukhâthab) who previously probably did not know. Maqâshid asy-syarî'ah from the determination of the eight asnaf is so that the distribution of zakat is not wrongly targeted.

However, there are differences of opinion among the scholars regarding the eight asnaf, is it the distribution to all of them or the only possible part? In this case there are two opinions, first it is obligatory to distribute to all asnaf, namely from the opinion of syafi'i along with the congregation. The second is not obliged to distribute to all asnaf but it can be one of them. This opinion is the opinion of Imam Malik and several people from the salaf and khalaf, including Umar, Hudzaifah, Ibn Abbas, Abul Aliyah, Sa'id bin Zubair and Maimun bin Mihran. Said Ibn Jarir, this is the opinion of most scientists. Based on this opinion, the purpose of mentioning the groups in this verse is to explain the groups entitled to receive zakat, not to explain the obligation to distribute it to all these groups. Therefore, distributing zakat to one of the asnaf is legally permissible.

The word shadaqât is zakat which is obligatory on the grounds that shadaqât is desired by all humans. Surely shadaqât is intended for all who have come (in al-Taubah [9]: 60). ${ }^{28}$ Allah has reserved some people with wealth as a form of pleasure from Him and made them grateful by sharing them with those who don't have them. ${ }^{29}$

In the above verse, Allah describes their ownership rights with lam which functions as lam tamlik (lam which means to have). According to Razaq al-Âini in the book: Masharif al-Zakat wa Tamlikuha fi Dhou 'al-Kitab wa al-Sunnah, as quoted by Moh. Thoriquddin stated that the letter lâm in the letter al-Taubah [9]: 60 is not li altamlik but li ajl means li ajli al-masraf (for distribution). Thus, the concept of mustahiq, which originally only meant people who had the right to receive and own zakat assets in full, were getting richer in meaning, that is, people who were entitled to receive a loan from zakat funds and return it did not fully own it.

According to the authors, what is meant by ownership (tamlik) of giving zakat funds is perfect ownership. Ownership is said to be perfect when there is a union between things and their benefits. ${ }^{30}$ With this perfect ownership, mustahiq can use zakat funds according to their needs, both consumptive and productive. However, with perfect ownership rights, sometimes the zakat funds that have been distributed are ineffective. This ineffectiveness can occur because the zakat funds given are only

${ }^{28}$ Abdurrahman bin Nâshir al-Sadi, Taisîr Al-Karîm Al-Rahman Fî Tafsîr Kalâmi Al-Mânan (Saudi Arabia: Dar al-Salâm, 1422).

${ }^{29}$ Al-Qurtubî, Al-Jâmi’ Li Ahkâm Al-Qur'ân, X (Beirut: Muasasah al-Risâlah, 1427).

${ }^{30}$ Ali Khafîfi, Al-Ahk m Al-Mu'âmalât Al-Syar'iyat (Kairo: Dâr al-Fikri al Arabî, 1429). 
limited or because the use factor has not yet touched productive businesses. Whatever causes the ineffectiveness of zakat funds must be immediately identified and a solution is found, so that the empowerment of the mustahiq does not fail.

\section{CONCLUSIONS AND IMPLICATIONS}

Based on the quantity of hadith under discussion, it is categorized as ahad hadith. Meanwhile, based on a critical review of the sanad and the observance of the hadith, the Dha'if/ weak level of munkar is due to a weakness / defect in one or several people who transmit the riwayah (rawi) of the hadith. However, on deeper analysis, this hadith is considered hasan lighairihi hadith, where the origin is dha'if but has reinforcement from other lines so that it is elevated to hasan lighairihi. In this hadith sanad there is a dha'if because one of the rawi is in the category of dhoif, but this hadith is strengthened from other hadith lines and does not contradict the verses of the qur'an so that it does not contain syadz and 'illah. In addition, the content of the Prophet's hadith regarding mashârif al-zakât which is the discussion does not contradict the verses of the qur'an, because it has the same meaning regarding the eight asnaf who are entitled to receive zakat.

\section{REFERENCE}

Abdullah Muhammad bin Yazid bin Majah ar-Rabi'i Al-Qazwini. Sunan Ibnu Majah. Cet. II,. Riyadh: Daar ul Ma'arif Linnasyri Wattaauzi', n.d.

Abdurrahman bin Ahmad bin Yunus al-Sadafi Abu Sa'id. Tarikh Ibn Yunus Al-Misr. Juz I, Cet. Beirut: Dar al-Kutub al-'Ilmiah, 1421.

Abdurrahman bin Nâshir al-Sadi. Taisîr Al-Karîm Al-Rahman Fî Tafsîr Kalâmi AlMânan. Saudi Arabia: Dar al-Salâm, 1422.

Abu 'Abillah Muhammad bin Sa'id bin Mani' al-Hasyimi. Tabaqah Al-Qubra. Madinah al-Munawwarh: Maktabah al-'Ulum wa al-Hukmi, 1408.

Abu Abdullah Malik bin Anas bin Malik bin Abu Amir Al-Ashbahi. Muwatha' Malik. Darul Ma'rifah, n.d.

Abu al-Fadl Ahmad bin 'Ali bin Muhammad bin Ahmad bin Hajar al-Asqalani. Tahzib Al-Tahzib. Juz I, Cet. Beirut: Dar al-Fikr al-'Arabiy, 1984.

Abu Daud Sulaiman bin Asy'ats as-Sijistani. Matan Sunan Abu Daud. Jilid 1. Baitul Afkar ad-Dauliyyah, n.d.

al-Islāmīyah, Kuwait. Wizārat al-Awqāf wa-al-Shu'ūn. Al-Mawsu'ah Al-Fiqhiyyah. Wizarat al-Awqaf wa al-Shu'un al-Islamiyah, 1982. https://books.google.co.id/books?id=VZdTnQAACAAJ.

Al-Qahthâni, Wahaf. Masharif Al-Zakat Fî Al-Islâmî. Riyâd: Muasasah al-Jarîsî, 1431. 
Al-Qurtubî. Al-Jâmi' Li Ahkâm Al-Qur'ân. X. Beirut: Muasasah al-Risâlah, 1427.

Ali, Muhammad. “Zakat Mal Dalam Kajian Hadis Maudhu'i." Aqidah-Ta 1, no. Vol 1, No 1 (2015) (2015): 69-98. http://journal.uin-alauddin.ac.id/index.php/aqidah$\mathrm{ta} /$ article/view/1310.

alKhadimi. Ilm Al-Maqâshid Al-Syar'iyyah. Riyadh: Maktabah Abikan, 1421.

Amarudin, Muchamat. "Optimalisasi Dana Zakat di Indonesia (Model Distribusi Zakat Berbasis Pemberdayaan Ekonomi): Muchamat Amarudin." EKSYAR: Jurnal Ekonomi Syari'ah \&amp; Bisnis Islam 6, no. 01 SE- (August 26, 2019): 1-13. https://ejournal.staim-tulungagung.ac.id/index.php/eksyar/article/view/380.

Fu'ad 'Abd. al-Baqy Muhammad. Al-Mu;Jam Al-Mufahras Li Alfazh Al Hadists AlNabawy. Juz II. Leiden, The Netherlands: E.J Brill, 1963.

Hames, Constant. "Wensinck (A.J.) Concordance et Indices de La Tradition Musulmane." Archives de Sciences Sociales Des Religions, 1993, 342. https://www.persee.fr/doc/assr_03355985_1993_num_82_1_1655_t1_0342_0000_2.

Hamzah, Hamzah. "Zakat Mal Dalam Perspektif Hadis Maudhu'iy." TASAMUH: Jurnal Studi Islam 11, no. 1 SE-Articles (April 1, 2019). https://doi.org/10.47945/tasamuh.v11i1.177.

Ibn Katsir. Tafsir Al-Qur'ân Al-'Adhîm. IV. Riyâd: Dâr al-Thyibah, 1418.

Ibnu Mubarak Abi Sa'adah Mubarrak. An-Nihayah Fi Gharib Al-Hadits Wal Atsar. Dar Al-Kutub, 1979.

Khafîfi, Ali. Al-Ahk m Al-Mu'âmalât Al-Syar'iyat. Kairo: Dâr al-Fikri al Arabî, 1429.

Makki, Mustaqim. "Tafsir Ayat-Ayat Zakat Sebagai Penguat Konsep Filantropi Ekonomi Keummatan (Tafsir Verses Of Zakat As The Booster Of Public Economic Philanthropy Concept)." Qawãnïn: Journal of Economic Syaria Law 3, no. 2 (2019): 117-37.

Mubasirun, Mubasirun. Distribusi Zakat dan Pemberdayaan Ekonomi Umat. INFERENSI. Vol. 7, 2013. https://doi.org/10.18326/infs13.v7i2.493-512.

Muslim bin al-Hajjaj Abu al-Hasan al-Qusyariyyi al-Naisaburi. Kuniyah Al-Asma. Juz. II. Madinah al-Munawwarh: Maktabah al-'Arabiyyah, 1984.

Nurudin, M. "Transformasi Hadis-Hadis Zakat Dalam Mewujudkan Ketangguhan Ekonomi Pada Era Modern." ZISWAF, no. Vol 1, No 2 (2014): ZISWAF : Jurnal Zakat dan Wakaf (2014): 1-22. http://journal.stainkudus.ac.id/index.php/Ziswaf/article/view/1489.

Penterjemah, Yayasan Penyelenggara, and Pentafsir Al-Qur'an. "Al-Qur'an Dan Terjemahnya." Jakarta: Departemen Agama, 1986.

Sa'id al-Mulk Abu Nasr 'Ali bin Hibbatillah bin Ma'ku. Al-Mausu'ah Al-Mujizah Fi Al-Tarikh Al-Islami. Juz V, Cet. Beirut: Dar al-Kutub al'Ilmiah, 1990.

Santoso, Ivan Rahmat. Manajemen Pengelolaan Zakat. Cet. I. Gorontalo: Ideas Publishing, 2016. 
Syarifuddin, Syarifuddin. "Zakat Fitrah (Kajian Hadis Tematik)." Al-Hikmah Journal for Religious Studies 14, no. 1 (2013): 93-111.

Wibowo, Arif. "Distribusi Zakat Dalam Bentuk Penyertaan Modal Bergulir Sebagai Accelerator Kesetaraan Kesejahteraan.” Jurnal Ilmu Manajemen UNY 12, no. 2 (2015): 28-43. https://doi.org/10.21831/jim.v12i2.11747. 